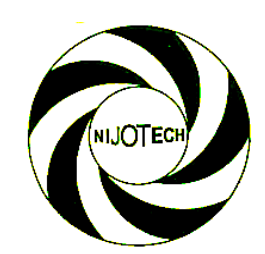

Nigerian Journal of Technology (NIJOTECH)

Vol. 37, No. 3, July 2018, pp. 799 - $\mathbf{8 0 5}$

Copyright@ Faculty of Engineering, University of Nigeria, Nsukka

Print ISSN: 0331-8443, Electronic ISSN: 2467-8821 www.nijotech.com

http://dx.doi.org/10.4314/nit.v37i3.32

\title{
MODELING GROUNDWATER QUALITY INDEX BASED ON SENSITIVITY ANALYSIS FOR WET AND DRY SEASONS IN OBIO/AKPOR LOCAL GOVERNMENT AREA, RIVERS STATE, NIGERIA
}

\author{
I. L. Nwaogazie ${ }^{1,}{ }^{*}$, O. P. Osamudiamen ${ }^{2}$ and O. Bovwe ${ }^{3}$

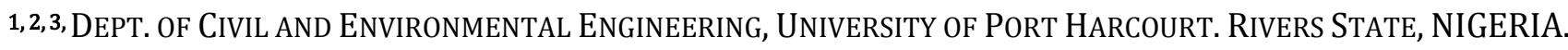 \\ E-mail addresses:1ifynwaogazie@yahoo.com, ${ }^{2}$ paulsamudia31@gmail.com, ${ }^{3}$ ofejiri@gmail.com
}

\begin{abstract}
This study was aimed at comparing groundwater quality of three communities namely Choba, Ekini and Ozuoba, all in Obio/Akpor Local Government Area in River State, Nigeria. Water samples from the functioning boreholes in these communities were collected and then analyzed physiochemically. Analysis of variance and weighted water quality index approach and multiple regression analyses were the methodologies employed for analyses of the collected data. Microsoft excel 2016 and an add-in (XLSTAT 2016) were the statistical tools used as aids for data analyses. The result from the analyses revealed poor water quality for Choba and Ozuoba communities with water quality indexes of 55.14 and 63.34, respectively. Ekini community has a good water quality rating with water quality index of 29.79. The developed model for prediction of water quality index for the communities revealed mean square errors, 0.000 and goodness of fits, 1.000. However, sensitivity analyses on the developed model parameters revealed that for Choba and Ekini communities, the major parameters with significant influence on the water quality index were $\mathrm{pH}$, Turbidity and Al. While for Ozuoba community, $\mathrm{pH}$, and Al had significant influence on the resultant water quality index based on the sensitivity analyses on the developed water quality index model.
\end{abstract}

Keywords: Groundwater, Quality Index, Sensitivity Analysis, Borehole, Obio/Akpor LGA, Rivers State.

\section{INTRODUCTION}

The intake of safe drinking water influences the level of human well-being. Safe water should not contain salts, must not contain any elements that cause offensive smell or taste, should not cause deterioration and should have a temperature moderate for utilization [1] Groundwater is the largest reservoir of drinkable water and it is less contaminated compared to surface water. However solid waste is potential sources of contamination of both surface and ground water [2]. According to Ayotamuno and Kogbara [3], Rivers State has increased level in Total Dissolved Solids (TDS) (up to $2900 \mathrm{mg} / \mathrm{l}$ ), high hydrocarbon content - oil and grease $(71 \mathrm{mg} / \mathrm{l}$ in 2006 compared to $1.8 \mathrm{mg} / \mathrm{l}$ recorded seventeen years earlier. Groundwater pollution occurs as a result of agricultural runoff water, flooding, oil spillage, industrial wastewater, lack of proper management or urban and natural decomposition of minerals that are harmful having interaction with the groundwater [4].

In Nigeria borehole water now serves as the easily accessed and cheap commercial source of drinking water. However, it is possible for groundwater quality to deteriorate over time and seasons. This study therefore was to compare the changes in ground water quality in the wet and dry seasons and to ascertain the level of significance of the variation. This informs on what extra treatments would be required in either season.

\section{MATERIALS AND METHODS}

\subsection{Study Area}

The study area (see Fig. 1) covered three communitiesChoba, Rumuekini (Ekini for short) and Ozuoba all in Obio/Akpor Local Government Area of Rivers State. Obio/Akpor is located within latitude 4.83153 and longitude 6.98906. It is bordered in the North by Ikwerre and Etche Local Government Areas, in the West by Emuoha Local Government Area, in the East by Omuma Local Government Area and Abia State, and in the South by Port Harcourt Local Government Area, respectively. 


\subsection{Data Collection}

Water samples were collected from Choba, Rumuekini and Ozuoba communities all in Obio/Akpor local government area of Rivers State. The samples were taken from private boreholes. It was ensured that they were taken directly from the boreholes and not from storage tanks to ascertain the exact quality of the groundwater. The temperature, $\mathrm{pH}$, and TDS were determined right at the point of collection. TDS was determined using a hand-held digital TDS meter measured to a precision of 0.1. The digital pen type $\mathrm{pH}$ meter [PH-009(I)] was employed for $\mathrm{pH}$ data collection. The measurement of Total Suspended Solid (TSS) was done by filtering a known volume of a sample, drying the filter and captured solids, then weighing the filter to determine the weight of the captured suspended solids in the sample. The weight of the captured solid divided by the volume of the sample was taken as the Total Suspended Solid. Finally, the tests for TSS, nitrate and aluminum were done in the laboratory by established standard methods.

\subsection{Data Analysis}

The methodology employed for data analyses were Analysis of variance (ANOVA) and multiple regression analyses. Also the approach of weighted arithmetic water quality index was applied for water quality index determination. Analysis of variance is a method for testing the hypothesis that there is no difference between two or more population means (usually at least two). It determines the significant difference between data by comparing their variability between groups and within groups. A One-Way Analysis of Variance was used in the analysis of the data. A oneway ANOVA is a way to test the equality of two or more means at one time by using variances.

Water quality index (WQI) provides a single number that expresses the general water quality at a certain location and time based on several water quality parameters. The goal of WQI is to transform numerous water quality data into information that is understandable and usable by the public. Basically, a WQI attempts to provide a mechanism for presenting a cumulatively derived, numerical expression defining a certain level of water quality. A single WQI value makes information much more easily understood than a long list of numerical values for a large variety of parameters [5] To evaluate the water quality index Equations ( 1 to 4 ) were applied. The calculation of WQI is given as follows by Odia, et al [5]:

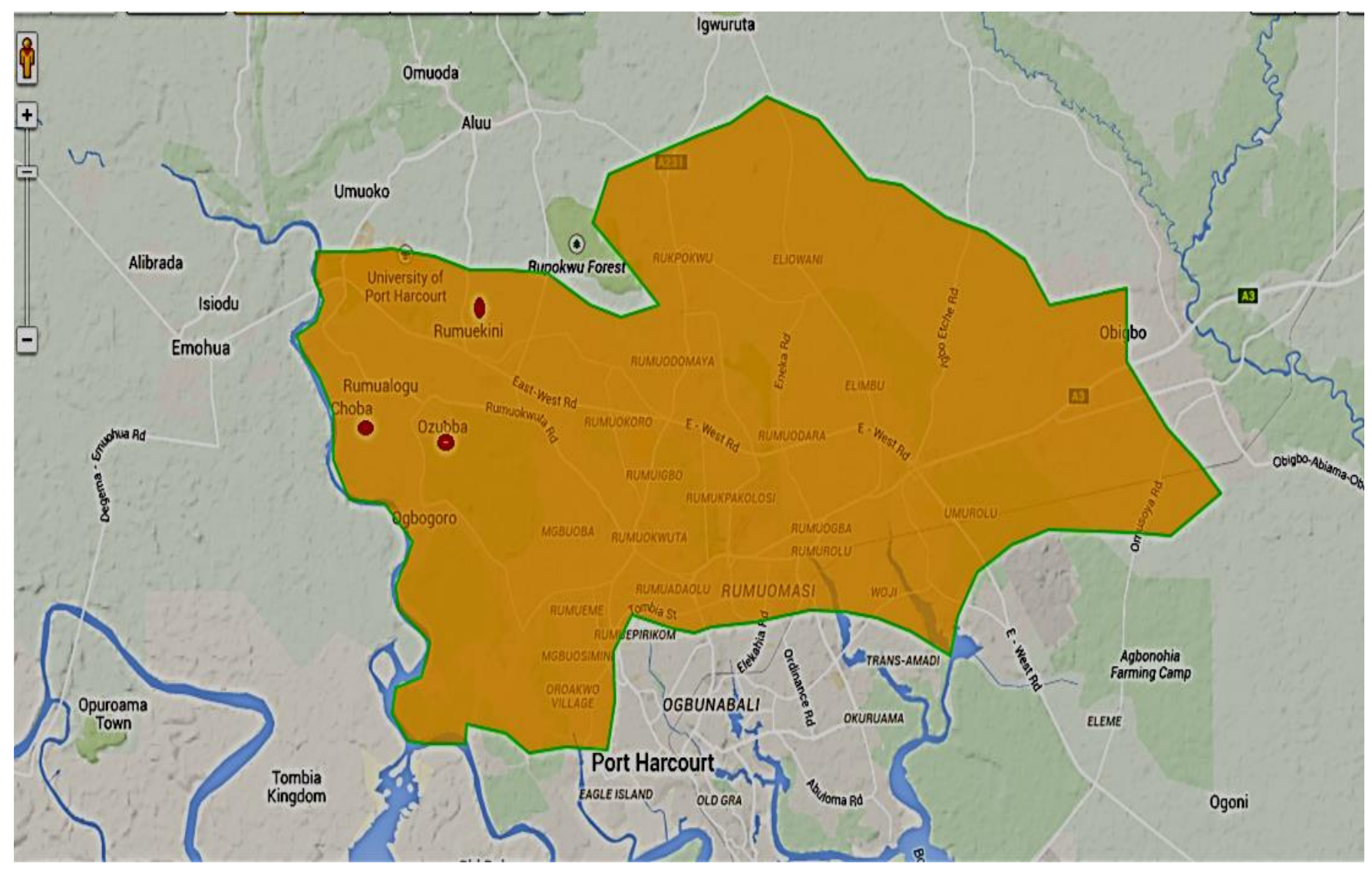

Figure 1: Map showing the locations of boreholes (source: modified from google-map) 


$$
W Q I=\frac{\sum Q_{j} w_{j}}{\sum w_{j}}
$$

The quality rating scale $\left(Q_{j}\right)$ for each parameter is calculated via Equation (2):

$$
Q_{j}=\left[\frac{v_{j}-v_{0}}{s_{j}-v_{0}}\right] \times 100
$$

where: $V_{j}$ is the Estimated concentration of the $\mathrm{n}^{\text {th }}$ parameter in the analyzed water sample; $v_{0}$ is the ideal value of analyzed water parameter in pure water sample which is usually zero except $\mathrm{pH}=7.0$ and dissolved oxygen, DO $=14.6 \mathrm{mg} / \mathrm{l} ; \quad s_{j}$ is the recommended standard value of $\mathrm{n}^{\text {th }}$ parameter which for this study was World Health Organization (WHO) and Nigeria Standard for Drinking Water Quality (NSDWQ). The unit weight $\left(\mathrm{w}_{\mathrm{j}}\right)$ for each water quality parameter is evaluated using Equation (3):

$$
w_{j}=\frac{k}{s_{j}}
$$

where $k=$ proportionality constant and can be evaluated by Equation (4)

$$
k=\frac{1}{\sum \frac{1}{s_{j}}}
$$

The water quality index rating is as presented in Table 1 :

\section{RESULTS AND DISCUSSION}

\subsection{Results}

Analyzing the collected physiochemical parameters from the sampled boreholes with respect to the sampling areas (Choba, Ekini and Ozuoba) Microsoft excel version 2017 and XLSTAT 2016 were employed as statistical tools. It is interesting to note that the collected data were assumed to be normally distributed with respect to this study. Thus, collected data were treated as parametric in nature.
Summary of results from the application of Analysis of Variance (ANOVA) at 5\% level of significance on the collected data are presented in Tables 2 and 3 . This was to assess for any significant differences between the physiochemical parameters of the water from the boreholes in the sampled locations. This is with respect to:

i) Wet and dry seasons from boreholes within same sampled areas (see Table 2); and

ii) From boreholes among the three sampled areas (Choba, Ekini and Ozuoba) using the average values of the physiochemical water parameters gathered (see Tables 3).

Table 1: Water quality rating as per weighted arithmetic water quality index

\begin{tabular}{lll}
\hline WQI values & Rating of water quality & Grade \\
\hline $0-25$ & Excellent & $\mathrm{A}$ \\
$26-50$ & Good & $\mathrm{B}$ \\
$51-75$ & Poor & $\mathrm{C}$ \\
$76-100$ & Very poor & $\mathrm{D}$ \\
Above 100 & Unsuitable for drinking purpose & $\mathrm{E}$ \\
\hline \multicolumn{3}{c}{ Source: Odia et al. [5] }
\end{tabular}

Furthermore, the Water Quality Index (WQI) of the various sampled boreholes (with respect to the three locations) for wet and dry seasons was estimated applying weighted arithmetic approach.

For illustration consider data with respect to Choba (dry season) sampled in week 1, applying Equations (1 to 4), Table 4 presents the calculation for the water quality index (WQI). Analogous to Table 4, the resultant of the WQI analysis for the three communities in wet and dry seasons sampled for 4 weeks each was evaluated. Tables 5 to 7 present the summary of the analysis for the water quality indexes.

Table 2: Summary of ANOVA Analyses between wet and dry season from boreholes within same sampled areas.

\begin{tabular}{cccccccc}
\hline \multirow{2}{*}{ Station } & \multicolumn{7}{c}{ P-Values } \\
\cline { 2 - 7 } & $\mathrm{pH}$ & TEMP & TDS & TSS & Nitrate & Aluminum & Turbidity \\
\hline Choba & 0.034 & 0.020 & 0.702 & 0.442 & 0.578 & 0.294 & 0.077 \\
Ekini & 0.289 & 0.004 & 0.801 & 0.182 & 0.378 & 0.416 & 0.184 \\
Ozuoba & 0.134 & 0.005 & 0.417 & 0.613 & 0.087 & 0.759 & 0.134 \\
\hline
\end{tabular}

Table 3: Summary of ANOVA Analyses of physiochemical parameters among the sampled communities

\begin{tabular}{lccccccc}
\hline & \multicolumn{7}{c}{ P-Values } \\
\cline { 2 - 7 } P-values among the 3 Communities & $\mathrm{pH}$ & TEMP & TDS & TSS & Nitrate & Aluminum & Turbidity \\
\cline { 2 - 8 } & 0.004 & 0.059 & 0.006 & 0.522 & 0.0005 & 0.104 & 0.346 \\
\hline
\end{tabular}


Modeling Groundwater Quality Index Based On Sensitivity Analysis For Wet And Dry Seasons.... I. L Nwaogazie, et al

Table 4: Calculation of WQI for Choba Dry Season, week 1

\begin{tabular}{lllllll}
\hline Parameters & $\mathrm{Wk1}$-DRY & $\mathrm{V}_{0}$ & $\mathrm{~S}_{\mathrm{j}}$ & $\mathrm{Q}_{\mathrm{j}}$ & $\mathrm{W}_{\mathrm{j}}$ & $\mathrm{Q}_{\mathrm{j}} \mathrm{W}_{\mathrm{j}}$ \\
\hline $\mathrm{pH}$ & 5.60 & 7.00 & 7.50 & -280.00 & 0.02 & -6.92 \\
$\mathrm{TDS}$ & 35.50 & 0.00 & 500.00 & 7.10 & 0.00 & 0.00 \\
$\mathrm{TUB}$ & 0.97 & 0.00 & 5.00 & 19.40 & 0.04 & 0.72 \\
$\mathrm{TSS}$ & 12.00 & 0.00 & 25.00 & 48.00 & 0.01 & 0.36 \\
$\mathrm{~N}$ & 3.70 & 0.00 & 50.00 & 7.40 & 0.00 & 0.03 \\
$\mathrm{Al}$ & 0.12 & 0.00 & 0.20 & 60.00 & 0.93 & 55.60 \\
\hline \multicolumn{3}{r}{$\mathrm{K}=1 / \sum\left(1 / \mathrm{S}_{\mathrm{j}}\right)=0.19$} & \multicolumn{5}{c}{$\mathrm{W}_{\mathrm{j}}=1$} & 49.79 \\
\hline
\end{tabular}

Table 5: Summary of WQI Calculation for Choba Community

\begin{tabular}{l|llll|llll}
\hline \multirow{2}{*}{ Parameters } & \multicolumn{4}{|c|}{ Dry Season } & \multicolumn{4}{c}{ Wet Season } \\
\cline { 2 - 8 } pH & Wk1 & Wk2 & Wk3 & Wk4 & Wk1 & WK2 & Wk3 & Wk4 \\
TDS & 5.60 & 5.65 & 5.50 & 5.40 & 5.25 & 5.25 & 5.25 & 5.50 \\
TUB & 35.50 & 27.30 & 15.00 & 20.00 & 30.60 & 22.95 & 20.20 & 15.20 \\
TSS & 0.97 & 1.07 & 0.31 & 0.22 & 1.15 & 1.16 & 1.03 & 0.96 \\
N & 12.00 & 12.00 & 10.00 & 7.50 & 9.50 & 11.50 & 8.50 & 7.50 \\
Al & 3.70 & 2.91 & 3.79 & 2.31 & 3.22 & 3.07 & 2.75 & 2.82 \\
WQI & 0.12 & 0.16 & 0.13 & 0.08 & 0.18 & 0.17 & 0.11 & 0.14 \\
\hline
\end{tabular}

Table 6: Summary of WQI Calculation for Ekini Community

\begin{tabular}{l|cccc|cccc}
\hline \multirow{2}{*}{ Parameters } & \multicolumn{4}{|c}{ Dry Season } & \multicolumn{4}{c}{ Wet Season } \\
\cline { 2 - 9 } pH & Wk1 & Wk2 & Wk3 & Wk4 & Wk1 & WK2 & Wk3 & Wk4 \\
TDS & 5.65 & 5.85 & 5.55 & 5.50 & 5.50 & 5.50 & 5.65 & 5.50 \\
TUB & 5.00 & 20.55 & 5.00 & 3.00 & 10.40 & 9.00 & 10.40 & 8.10 \\
TSS & 0.80 & 0.80 & 0.53 & 0.19 & 0.88 & 1.05 & 0.84 & 0.93 \\
N & 9.50 & 9.00 & 10.00 & 6.00 & 10.00 & 12.00 & 9.50 & 9.50 \\
Al & 1.84 & 2.57 & 1.80 & 2.66 & 2.70 & 1.43 & 3.29 & 3.39 \\
WQI & 0.03 & 0.15 & 0.03 & 0.04 & 0.13 & 0.15 & 0.05 & 0.05 \\
\hline
\end{tabular}

Table 7: Summary of WQI Calculation for Ozuoba Community

\begin{tabular}{l|cccc|cccc}
\hline \multirow{2}{*}{ Parameters } & \multicolumn{4}{|c|}{ Dry Season } & \multicolumn{4}{c}{ Wet Season } \\
\cline { 2 - 9 } pH & Wk1 & Wk2 & Wk3 & Wk4 & Wk1 & WK2 & Wk3 & Wk4 \\
TDS & 5.60 & 5.50 & 5.50 & 5.60 & 5.50 & 5.50 & 5.50 & 5.50 \\
TUB & 20.50 & 25.50 & 26.00 & 20.50 & 22.50 & 26.00 & 11.50 & 20.50 \\
TSS & 0.95 & 0.85 & 0.95 & 0.95 & 1.00 & 1.12 & 0.93 & 0.90 \\
N & 12.00 & 11.50 & 10.00 & 9.50 & 11.50 & 10.00 & 10.00 & 10.00 \\
Al & 2.76 & 2.95 & 8.99 & 12.82 & 30.14 & 19.50 & 28.93 & 3.35 \\
WQI & 0.16 & 0.21 & 0.15 & 0.11 & 0.20 & 0.18 & 0.16 & 0.05 \\
\hline
\end{tabular}

The calculated water quality indexes and the collected water parameters were further employed to develop site specific models (using XLSTAT 2016 statistical software) with respect to the three communities. In developing the models, multiple linear regression approach with sensitivity analyses was applied. The calculated water quality indexes were assumed as the dependent variable while the physiochemical parameters from the boreholes within sampled communities were assumed as the independent variables. Sensitivity analysis was carried out to determine which parameter influences the water quality indexes the most. In order to select the best models, the minimum resultant means square error from the models was used. Tables 8 to 10 present the summary of the developed models with sensitivity analysis output (in that order). Also, Equations (5 to 7) present the resultant best model from sensitivity analyses output for the three communities. 
Modeling Groundwater Quality Index Based On Sensitivity Analysis For Wet And Dry Seasons.... I. L Nwaogazie, et al

Table 8: Summary of Model outputs with sensitivity analysis (Choba Community)

\begin{tabular}{lllll}
\hline No. of variables & Variables & MSE & $\mathrm{R}^{2}$ & Adjusted R $^{2}$ \\
\hline 1 & $\mathrm{Al}$ & 0.7885 & 0.9974 & 0.9970 \\
2 & $\mathrm{Al} / \mathrm{pH}$ & 0.0635 & 0.9998 & 0.9998 \\
$3 \pm$ & $\mathrm{Al} / \mathrm{pH} /$ TUB & 0.0032 & 1.0000 & 1.0000 \\
4 & $\mathrm{Al} / \mathrm{pH} / \mathrm{TUB} / \mathrm{TSS}$ & 0.0000 & 1.0000 & 1.0000 \\
5 & $\mathrm{Al} / \mathrm{pH} / \mathrm{TUB} / \mathrm{TSS} / \mathrm{N}$ & 0.0000 & 1.0000 & 1.0000 \\
6 & $\mathrm{Al} / \mathrm{pH} / \mathrm{TUB} / \mathrm{TSS} / \mathrm{N} / \mathrm{TDS}$ & 0.0000 & 1.0000 & 1.0000 \\
\hline
\end{tabular}

\pm The best model based on selection criterion

Table 9: Summary of Model outputs with sensitivity analysis (Ekini Community)

\begin{tabular}{lllll}
\hline No. of variables & Variables & MSE & $\mathrm{R}^{2}$ & Adjusted R $^{2}$ \\
\hline 1 & $\mathrm{Al}$ & 0.4596 & 0.9994 & 0.9993 \\
2 & $\mathrm{Al} / \mathrm{pH}$ & 0.0607 & 0.9999 & 0.9999 \\
$3 \pm$ & $\mathrm{Al} / \mathrm{pH} / \mathrm{TUB}$ & 0.0008 & 1.0000 & 1.0000 \\
4 & $\mathrm{Al} / \mathrm{pH} / \mathrm{TUB} / \mathrm{TSS}$ & 0.0000 & 1.0000 & 1.0000 \\
5 & $\mathrm{Al} / \mathrm{pH} / \mathrm{TUB} / \mathrm{TSS} / \mathrm{N}$ & 0.0000 & 1.0000 & 1.0000 \\
6 & $\mathrm{Al} / \mathrm{pH} / \mathrm{TUB} / \mathrm{TSS} / \mathrm{N} / \mathrm{TDS}$ & 0.0000 & 1.0000 & 1.0000 \\
\hline
\end{tabular}

\pm The best model based on selection criterion

Table 10: Summary of Model outputs with sensitivity analysis (Ozuoba Community)

\begin{tabular}{lllll}
\hline No. of variables & Variables & $\mathrm{MSE}$ & $\mathrm{R}^{2}$ & Adjusted R $^{2}$ \\
\hline 1 & $\mathrm{Al}$ & 0.0642 & 0.9999 & 0.9999 \\
$2 \pm$ & $\mathrm{Al} / \mathrm{pH}$ & 0.0157 & 1.0000 & 1.0000 \\
3 & $\mathrm{Al} / \mathrm{pH} / \mathrm{TUB}$ & 0.0046 & 1.0000 & 1.0000 \\
4 & $\mathrm{Al} / \mathrm{pH} / \mathrm{TUB} / \mathrm{TSS}$ & 0.0009 & 1.0000 & 1.0000 \\
5 & $\mathrm{Al} / \mathrm{pH} / \mathrm{TUB} / \mathrm{TSS} / \mathrm{N}$ & 0.0000 & 1.0000 & 1.0000 \\
6 & $\mathrm{Al} / \mathrm{pH} / \mathrm{TUB} / \mathrm{TSS} / \mathrm{N} / \mathrm{TDS}$ & 0.0000 & 1.0000 & 1.0000 \\
\hline
\end{tabular}

\pm The best model based on selection criterion

Developed Model of Water Quality Index for Choba:

Option 3:

$$
W Q I=-35.31+5.11 p H+0.77 T U B+464.133 A l
$$

Option $6^{ \pm}$:

$$
W Q I=-34.60+4.94 p H+0.00007 T D S+0.74 T U B+0.03 T S S+0.007 \mathrm{~N}+463.36 \mathrm{Al}
$$

Developed Model of Water Quality Index for Ekini:

Option 3:

$$
W Q I=-34.07+4.88 p H+0.90 T U B+463.37 A l
$$

Developed Model of Water Quality Index for Ozuoba:

Option 2:

$$
W Q I=-31.72+4.90 p H+464.43 A l
$$

NOTE: \pm Equation (5b) for Choba is same for Ekini and Ozuoba that is, WQI model without the benefit of sensitivity analysis (that is, parameter reduction).

\subsection{Discussion}

Assessment of Groundwater Quality of the Study Area The study area for this research was limited to three communities located in Obio/Akpor Local Government Area of Rivers State. Water samples were collected from boreholes within these communities during the wet and dry seasons for 8 weeks. In the wet season, the ranges of physiochemical parameter values were 20.6 ${ }^{\circ} \mathrm{C} \leq$ Temperature $\leq 23.0^{\circ} \mathrm{C} ; 5.0 \leq \mathrm{pH} \leq 6.0 ; 6.0 \mathrm{mg} / \mathrm{l} \leq$ TDS $\leq 37.8 \mathrm{mg} / \mathrm{l} ; 7.0 \mathrm{mg} / \mathrm{l} \leq \mathrm{TSS} \leq 14.0 \mathrm{mg} / \mathrm{l} ; 0.03 \mathrm{mg} / \mathrm{l}$ 
$\leq \mathrm{Al} \leq 0.28 \mathrm{mg} / \mathrm{l} ; 1.15 \mathrm{mg} / \mathrm{l} \leq$ Nitrate $\leq 58.2 \mathrm{mg} / \mathrm{l}$ and 0.74 N.T.U $\leq$ Turbidity $\leq 1.24$ N.T.U. In the dry season, the $\mathrm{pH}$, temperature and TDS were generally higher compared to the wet season. TDS is a function of Temperature and $\mathrm{pH}$. At higher temperatures and lower $\mathrm{pH}$, groundwater dissolves more minerals. The ranges of values were $22.6^{\circ} \mathrm{C} \leq$ Temperature $\leq 23.4$ ${ }^{\circ} \mathrm{C} ; 5.5 \leq \mathrm{pH} \leq 6.0 ; 2.0 \mathrm{mg} / \mathrm{l} \leq \mathrm{TDS} \leq 40.0 \mathrm{mg} / \mathrm{l} ; 5.0 \mathrm{mg} / \mathrm{l}$ $\leq$ TSS $\leq 12.0 \mathrm{mg} / \mathrm{l} ; 0.02 \mathrm{mg} / \mathrm{l} \leq \mathrm{Al} \leq 0.26 \mathrm{mg} / \mathrm{l}$; $1.71 \mathrm{mg} / \mathrm{l} \leq$ Nitrate $\leq 23.0 \mathrm{mg} / \mathrm{l}$; and 0.19 N.T.U $\leq$ Turbidity $\leq 1.16$ N.T.U.

The results from the analyses of variance revealed that with respect to the wet and dry season, there exist a significant difference between physiochemical parameters such as $\mathrm{pH}$ and Temperature for water sampled from Choba community; temperature only for Ekini and Ozuoba communities (see Table 2). However, among the three communities the significant variation was with respect to $\mathrm{pH}$, temperature, total dissolved solids and nitrate (see Table 3).

From Tables 5 to 7 , the average water quality with respect to the calculated quality indexes for Choba, Ekini and Ozuoba were 55.14, 29.79 and 63.34, respectively. From the resultant average water quality indexes, the water quality from Choba, Ekini and Ozuoba are rated poor (grade C), good (grade B) and poor (grade C), respectively (see Table 1 ). Thus, the water from Ekini rated of a better quality to that from Choba and Ozuoba. However, comparing the water quality of Choba and Ozuoba, Choba has a better average water quality (see Tables 5 and 7). Furthermore, the average water quality index for the areas covered by the sampled three communities is 49.42. This finding agrees with the water quality evaluated for river in Enugu urban area by Ezemonye [6] where the quality of waters obtained from rivers within the urban areas of Enugu were rated poor having water quality index range of 47 to 66 . Also, the finding of Oko et al. [7] agrees with that of this study. Oko et al. [7] studied the water quality of borehole and well waters from Wukari town in Taraba State, Nigeria. The resultant ratings for the quality of water from majority of the sampled boreholes in that area fell between grade $\mathrm{C}$ and $\mathrm{D}$, thus, rating the water not fit for drinking. Furthermore, the study on the water quality index assessment from different sources in the Niger Delta region by Etim et al. [8] agrees with the findings from this research.

\subsection{Sensitivity Analysis of Physiochemical Parameters on Water Quality.}

The developed models predicting the water quality index of sampled water from the study areas were subjected to sensitivity analyses. This is to assess the effect of the individual parameter evaluated on the resultant water quality. The best models from the analyses were selected with respect to minimum Means Square Error (MSE). With respect to Choba, Ekini and Ozuoba communities, the best models selected had means square errors of 0.000 and goodness of fits of 1.0. However, for Choba community the major parameters with significant influence based on the sensitivity analyses on the water quality index were $\mathrm{pH}$, Turbidity and $\mathrm{Al}$ (MSE $=0.0032$ and goodness of fit $=1.000$ ). Also, Ekini community had same major parameters influencing the resultant water quality based on the developed model but with mean square error of 0.0008 and goodness of fit of 1.000 . While for Ozuoba community it was $\mathrm{pH}$ and $\mathrm{Al}$ that had significant influence on the resultant water quality index with a means square error of 0.0157 and goodness of fit 1.0. The finding from this study agrees with the work of Odia et al. [5] where principal component analyses was applied to determine the principal physiochemical elements of water sampled from dug wells and boreholes around three major dumpsites in Delta State, Nigeria.

\section{CONCLUSION}

The conclusions drawn from this study include:

i) There is significant differences between physiochemical parameters such as $\mathrm{pH}$ and Temperature for water sampled from Choba community during the wet and dry season;

ii) Temperature is the only physiochemical property that varied between the dry and wet seasons for Ekini and Ozuoba communities.

iii) Among Choba, Ekini and Ozuoba communities three physiochemical parameters that varied were with respect to $\mathrm{pH}$, temperature, total dissolved solids and nitrate.

iv) The average water quality from the average water quality indexes from Choba, Ekini and Ozuoba are rated poor (grade C), good (grade B) and poor (grade C), respectively.

v) Taking the average water quality indexes for the areas covered by the sampled three communities together revealed the possibility of having a good water quality with water quality index of 49.42 .

vi) Two multiple regression models were developed each for the three communities based on 
sensitivity analyses with $\mathrm{R}^{2}$ values ranging from 0.9974 to $1.000,0.9994$ to $1.000,0.9999$ to 1.000 and means square error ranging from 0.000 to $0.7885,0.000$ to $0.4596,0.000$ to 0.0642 for Choba, Ekini and Ozuoba communities respectively.

vii) For Choba and Ekini communities, the major parameters with significant influence based on the sensitivity analyses on the water quality index model developed from this study were $\mathrm{pH}$, Turbidity and Al.

viii) For Ozuoba community, $\mathrm{pH}$ and $\mathrm{Al}$ had significant influence on the resultant water quality index based on the sensitivity analyses on the developed water quality index model.

\section{REFERENCES}

[1] Rashel Nirjhon: "Supply Water Quality of Tangail Municipality", www.hubpages.com, 2010.

[2] Odukoya, 0. O. \& Arowolo, Toyin \& Bamgbose, 0. Effect of solid waste landfill on underground and surface water quality at ring road, Ibadan, Nigeria. Global Journal of Environmental Sciences. 1. 10.4314/gjes.v1i1.2396. 2002.

[3] Ayotamuno, M. J and Kogbara, R. B: Response of Environmental Characteristics to Industrialisation: A case study of the Onne oil and gas $J$. of food, agriculture and environment" vol. 5(1) 288-289, 2007

[4] Nwaogazie, I. L. Water Supply for All: Who Cares? Inaugural Lecture Series No. 52, University of Port Harcourt, July 27, pp109. 2006.

[5] Odia, M., and Nwaogazie, I. L. Multivariate Statistical Approach in Modeling Surface and Groundwater Quality near Municipal Solid Waste Dumpsites in Warri Metropolitan City. Archives of Current Research International, Vol.8, No. 4, pp.121. 2017.

[6] Ezemonye, M. N.. Assessment of water quality of rivers in Enugu Urban Area of Nigeria. Afr. J. Environ. Pollut. Health. Vol.9, No.1, pp 42-49, 2011.

[7] Oko, O. J., Aremu, M. O., Odoh, R., Yebpella, G. and Shenge, G. A. Assessment of Water Quality Index of Borehole and Well Water in Wukari Town, Taraba State, Nigeria. Journal of Environment and Earth Science. Vol. 4, No.5, pp. 1-9, 2014.

[8] Etim, E. E., Odoh, R., Itodo, A. U., Umoh, S. D., and Lawal, U. Water Quality Index for the Assessment of Water Quality from Different Sources in the Niger Delta Region of Nigeria. Frontiers in Science. Vol.3, No.3, pp. 89-95. 